\title{
Pengaruh Dosis Pupuk Kotoran Sapi yang Berbeda Terhadap Pertumbuhan Keong Bakau (Telescopium telescopium) yang Dipelihara pada Substrat Lumpur
}

\author{
The Effect of Different Doses of cow manure as natural fertilizer on the Growth of \\ Mangrove Snails (Telescopium telescopium) Maintained on the Mud Substrate
}

\author{
Asban, Agus Kurnia*, Ruslaini, \\ Program Studi/Jurusan Budidaya Perairan, Fakultas perikanan dan Ilmu Kelautan Universitas Halu Oleo \\ Jl. HEA Mokodompit Kampus Bumi Tridharma Anduonohu Kendari 93232 Telp/Fax (0401) 3193782 \\ "Email korespondensi : aguskurnia@yahoo.com
}

\begin{abstract}
ABSTRAK
Penelitian ini bertujuan untuk mengetahui pengaruh dosis kotoran sapi yang berbeda terhadap pertumbuhan keong bakau (Telescopium telescopium) yang dipelihara pada substrat lumpur. Tiga dosis pupuk kotoran sapi ditambahkan kedalam subtrat lumpur sebanyak $500 \mathrm{~g} / \mathrm{m}^{2}, 1000 \mathrm{~g} / \mathrm{m}^{2}, 1500 \mathrm{~g} / \mathrm{m}^{2}$ dan kontrol. Masing-masing 20 ekor keong bakau (rata-rata bobot awal rata-rata 7,63 $\pm 0,19 \mathrm{~g}$ ) dimasukkan kedalam 12 wadah baskom dan dipelihara selama 56 hari. Variabel yang diamati adalah pertumbuhan mutlak, laju pertumbuhan spesifik, pertumbuhan panjang cangkang dan kelangsungan hidup keong bakau. Hasil penelitian menunjukan pemberian pupuk kotoran sapi dengan dosis yang berbeda memberikan pengaruh yang tidak berbeda nyata terhadap pertumbuhan mutlak, pertumbuhan panjang cangkan, laju pertumbuhan spesifik dan kelangsungan hidup keong bakau. Pemberian pupuk kotoran sapi dengan dosis $500 \mathrm{~g} / \mathrm{m}^{2}, 1000 \mathrm{~g} / \mathrm{m}^{2}$ dan $1500 \mathrm{~g} / \mathrm{m}^{2}$ memberikan pertumbuhan mutlak rata-rata masing-masing sebesar $0,30 \mathrm{~g}, 0,56 \mathrm{~g}$ dan 0,41 g, secara berturut-turut. Laju pertumbuhan spesifik berkisar $0,10-0,35 \%$ pada hari ke-14, 0,08-0,22\% pada hari ke-28, 0,06-0,16\% pada hari ke-42 dan 0,06-0,13\% pada hari ke-56. Pertumbuhan mutlak panjang cangkang keong bakau pada tiga perlakuan dosis pupuk masingmasing sebesar $0,09 \mathrm{~cm}$ pada dosis $500 \mathrm{~g} / \mathrm{m}^{2}, 0,12 \mathrm{~cm}$ pada dosis $1000 \mathrm{~g} / \mathrm{m}^{2}$ dan $0,05 \mathrm{~cm}$ pada dosis $1500 \mathrm{~g} / \mathrm{m}^{2}$. Kelangsungan hidup keong berkisar antara 98,3-100\%. Penelitian ini menyimpulkan bahwa pemberian pupuk kotoran sapi dapat meningkatkan pertumbuhan keong bakau.
\end{abstract}

Kata kunci: pupuk, kotoran sapi, pertumbuhan keong bakau, Telescopium telescopium

\begin{abstract}
This study aims to determine the effect of different doses of cow manure as natural fertilizer on the growth of mangrove snails (Telescopium) that reared in the mud substrate. Three doses of cow manure were supplied in the mud substrat namely $500 \mathrm{~g} / \mathrm{m} 2,1000 \mathrm{~g} / \mathrm{m} 2$ and $(1500 \mathrm{~g} / \mathrm{m} 2$, respectively and one subtrat without supplied with cow manure as a control. Each of 20 mangrove snails (initial weight :7.63 $\pm 0.19 \mathrm{~g}$ ) were distibuted into 12 plastic basin and they were reared for 56 days. The variables observed were average weight gain, specific growth rate, weight gain of shell length and survival rate of mangrove snails. The results showed that supplementation of cow manure with different doses were not significantly different in weight gain, growth in shell length, specific growth rates and the survival rate of mangrove snails. Supplemetation of cow manure in mangrove snails in subtrate with a dose of $500 \mathrm{~g} / \mathrm{m}^{2}, 1000 \mathrm{~g} / \mathrm{m}^{2}$ and $1500 \mathrm{~g} / \mathrm{m}^{2}$ resulted the weight gain of mangrove snail were $0.30 \mathrm{~g}$ at a dose of $500 \mathrm{~g} / \mathrm{m}^{2}, 0.56 \mathrm{~g}$ at a dose of $1000 \mathrm{~g} / \mathrm{m}^{2}$ and $0.41 \mathrm{~g}$ at a dose of $1500 \mathrm{~g} / \mathrm{m}^{2}$, respectivley. The specific growth rate of mangrove snail in supplemetantion of three doses of cow manure were $0.10-0.35 \%$ on day $14,0.08-0.22 \%$ on day $28,0.06-0.16 \%$ on day 42 and $0.06-0.13 \%$ on the 56 th day, respctively. The weight gain of shell length of mangrove snail in three doses of cow manure were $0.09 \mathrm{~cm}$ at a dose of $500 \mathrm{~g} / \mathrm{m}^{2}, 0.12 \mathrm{~cm}$ at a dose of $1000 \mathrm{~g} / \mathrm{m}^{2}$ and $0.05 \mathrm{~cm}$ at a dose of $1500 \mathrm{~g} / \mathrm{m}^{2}$.The survival rates of mangrove snails were range from $98.3-100 \%$. In conclusion, supplementation of cow manure as natural fertilizer in substrate of mangrove snail could increase the gowth of mangrove snail.
\end{abstract}

Keywords: natural fertilizer, cow manure, growth of mangrove snail, Telescopium telescopium

\section{PENDAHULUAN}

Salah satu faktor penting dalam kegiatan budidaya adalah manajemen pemberian pakan. Hal ini disebabkan karena $40 \%-60 \%$ biaya produksi dialokasikan untuk pakan. Salah satu makro molekul dalam bahan pakan yang penting untuk pertumbuhan organisme budidaya adalah protein. Selama ini bahan pakan sumber protein yang digunakan adalah tepung ikan. Namun dalam dekade terakhir ini produksi tepung ikan dunia menurun seiring dengan menurunnya produksi perikanan tangkap dunia. Oleh karena itu perlu dicari sumber bahan pakan pengganti tepung ikan (Kurnia et al. 2016)

Salah satu bahan pakan sumber protein yang berpotensi mengganti tepung ikan adalah tepung keong bakau. Keong bakau memiliki kandungan protein yang cukup tinggi sehingga 
berpotensi dijadikan bahan alternatif sumber protein hewani dalam pakan ikan. Kurnia et al. (2016) menyatakan tepung keong bakau mengandung protein $67,6 \%$, lemak $6,35 \%$, air 9,64\% dan kadar kadar abu $7,72 \%$. Pemanfaatan keong bakau dijadikan bahan pakan akan menjadi kehawatiran tersendiri akan menurunya produksi keong bakau di alam. Oleh karena itu perlu dilakukan usaha budidaya keong bakau untuk menjaga kelestarian populasi keong bakau di alam.

Budidaya keong bakau memerlukan substrat yang kaya akan nutrient karena pada dasarnya habitat keong bakau adalah lumpur berpasir di daerah manggrove yang kaya nutrient. Pemberian pupuk organik dalam media pemeliharaan keong bakau mutlak perlu dilakukan (Hamsiah, 2002).

Salah satu pupuk alami yang berpotensi yang dapat dimanfaatkan dalam memberikan sumbangan nutrient untuk kesuburan media pemeliharaan keong bakau adalah kotoran sapi. Zahidah $d k k$ (2012) menyatakan bahwa nutrisi dapat berasal dari banyak sumber, diantara dari bahan organik tersuspensi dan bakteri yang diperoleh dari pupuk yang ditambahkan ke dalam media kultur. Menurut Berova (2010) bahwa penggunaan pupuk kotoran sapi memiliki kandungan $0,402 \% \mathrm{~N}, 0,20-0,50 \% \mathrm{P}$ dan $0,10-1,5 \% \mathrm{~K}$.

Namun informasi tentang penggunaan dosis kotoran sapi sebagai pupuk alami dalam pemeliharaan keong bakau masih sangat terbatas. Oleh karena itu, perlu dilakukan penelitian pengaruh dosis kotoran sapi yang berbeda terhadap pertumbuhan keong bakau (Telescopium telescopium) yang dipelihara pada substrat lumpur.

\section{BAHAN DAN METODE}

Penelitian ini dilakukan pada bulan Maret sampai Mei 2019, di Laboratorium Unit Pembenihan dan Produksi Ikan, Fakultas Perikanan dan Ilmu kelautan Universitas Halu Oleo.

\section{Persiapan Pupuk Kotoran Sapi}

Pupuk yang digunakan selama penelitian ini adalah kotoran sapi yang berasal dari kandang peternakan sapi di rumah pemotongan hewan di Kecamatan Poasia, Kendari dengan kondisi masih basah. Kotoran sapi tersebut dikeringkan langsung di bawah sinar matahari selama 3 hari atau sampai kering, kemudian difermentasi menggunakan EM4 (Effective Microorganisme). Fermentasi bertujuan meningkatkan kualitas dan mempercepat proses dekomposisi bahan organik yang terkandung dalam kotoran sapi. Fermentasi dilakukan berdasarkan penelitian Masithah $d k k$. (2011), proses fermentasi ini diawali dengan mencampur air gula 4\%, $150 \mathrm{ml}$ air, $500 \mathrm{~g}$ kotoran sapi dan EM4 sebanyak $10 \mathrm{ml}$ kemudian diaduk merata dan diinkubasi selama 5 hari pada suhu $27-32^{\circ} \mathrm{C}$. Kotoran sapi hasil fermentasi kemudian dikeringkan langsung di bawah sinar matahari selama 3 hari.

Pupuk kotoran sapi langsung ditebar ke dalam baskom dimana pupuk ini berfungsi untuk memperkaya kandungan nutrient dalam media budidaya. Pemberian pupuk dilakukan sesuai perlakuan setiap dosis yang telah ditentukan yaitu perlakuan $\mathrm{A}$ : tanpa pemberian pupuk (kontrol), B : $500 \mathrm{~g} / \mathrm{m}^{2}$, perlakuan $\mathrm{C}$ : $1000 \mathrm{~g} / \mathrm{m}^{2}$ dan perlakuan D : $1500 \mathrm{~g} / \mathrm{m}^{2}$.

\section{Penebaran dan Pemeliharaan Keong Bakau}

Total keong bakau yang digunakan sebanyak 240 ekor dengan berat awal rata-rata sebesar 7,63 $\pm 0,19$ g. Setiap baskom diisi 20 ekor keong bakau. Keong bakau yang digunakan berasal perairan Desa Tanjung Tiram kec. Moramo Kab. Konawe Selatan . Sebelum dimasukkan di dalam baskom hewan uji diadaptasikan terlebih dahulu selama 1 hari di dalam baskom.

Keong bakau yang digunakan dalam penelitian terlebih dahulu ditampung di dalam baskom, sebelum melakukan penebaran keong bakau ditimbang untuk memperoleh berat awal dan Panjang cangkang keong bakau. Penebaran keong bakau ke wadah pemeliharaan dilakukan pada sore hari. Penimbangan berat dan pengukuran Panjang cangkang keong bakau dilakukan setiap 14 hari selama 56 hari masa pemeliharaan. Selanjutnya, selama masa pemeliharaan berlangsung dilakukan pengukuran kualitas air.

\section{Rancangan Penelitian}

Penelitian ini menggunakan Rancangan Acak Lengkap (RAL), yang terdiri dari 4 perlakuan dan 3 ulangan.

\section{Variabel yang Diamati}

\section{Pertumbuhan Mutlak Keong Bakau}


Pertumbuhan mutlak dihitung dengan menggunakan rumus $\mathrm{Hu}$ et al. (2008).

$$
\mathrm{PM}=\mathrm{Wt}-\mathrm{W} 0
$$

Dimana: $\mathrm{PM}=$ Pertumbuhan mutlak rata-rata $(\mathrm{g}), \mathrm{Wt}=$ Berat rata-rata individu pada akhir penelitian $(\mathrm{g})$, W0 = Berat rata-rata individu pada awal penelitian $(\mathrm{g})$.

\section{Pertumbuhan Panjang Cangkang}

Pertumbuhan mutlak cangkang dihitung berdasarkan pertambahan tinggi cangkang keong bakau. Pertumbuhan mutlak cangkang dihitung dengan menggunakan rumus Effendi (2003).

$$
\mathrm{PM}=\mathrm{L} 1-\mathrm{L} 0
$$

Dimana: PM = Pertumbuhan mutlak cangkang $(\mathrm{mm}), \mathrm{L} 1=$ Tinggi cangkang pada akhir pengamatan $(\mathrm{mm}), \mathrm{L} 0=$ Tinggi cangkang pada awal pengamatan $(\mathrm{mm})$.

\section{Laju Pertumbuhan Spesifik}

Laju pertumbuhan spesifik (Spesifik Growth Rate) adalah persentase pertambahan berat keong bakau setiap harinya selama pemeliharaan. Laju pertumbuhan spesifik dilakukan dengan menggunakan rumus menurut Kusriani $d k k$. (2012).

$$
\text { LPS }=\frac{\text { Ln Wt-Ln W0 }}{\mathrm{t}} \times 100 \%
$$

Dimana: LPS = Laju pertumbuhan spesifik (\%), $\mathrm{W} 0=$ Bobot rata-rata hewan uji pada awal penelitian $(\mathrm{g})$, Wt $=$ Bobot rata-rata hewan uji pada akhir penelitian (g), $\mathrm{t}$ = Lama waktu pemeliharaan (hari).

\section{Tingkat Kelangsungan Hidup}

Tingkat kelangsungan hidup dapat dihitung menggunakan rumus Effendi (1997).

$$
\mathrm{SR}=\frac{\mathrm{Nt}}{\mathrm{N} 0} \times 100 \%
$$

Dimana: $\mathrm{SR}=$ Tingkat kelangsungan hidup $(\%), \mathrm{Nt}=$ Jumlah individu pada akhir penelitian (ekor), $\mathrm{N} 0=$ Jumlah individu pada akhir penelitian (ekor).

\section{Analisis Bahan Organik}

Analisis bahan organik menggunakan metode Spektrofotometer.

\section{Uji Proksimat Daging Keong Bakau}

Uji proksimat dilakukan dengan mengukur kadar protein dan kadar air dari daging keong bakau. Analisis kadar protein menggunakan metode Kjeldhal (AOAC, 1970) sedangkan analisis kadar air menggunakan metode Gravimetri (AOAC, 1970).

\section{Analisa Data}

Pertumbuhan mutlak biomassa, pertumbuhan mutlak cangkang, laju pertumbuhan spesifik dan kelangsungan hidup dianalisis menggunakan Analysis of Variance (ANOVA) dengan taraf kepercayaan 95\%. Sedangkan data kualitas air dianalisis secara deskriptif. Jika analisis ragam menunjukkan hasil yang berpengaruh nyata maka dilakukan uji lanjut dengan Duncan. Seluruh analisis data dilakukan dengan bantuan Statistical Product and Service Solutions (SPSS) for Windows Versi 16,0.

\section{HASIL}

\section{Pertumbuhan Mutlak Keong Bakau}

Hasil perhitungan pertumbuhan mutlak keong bakau selama penelitian disajikan pada Gambar 1. Hasil analisis ragam menunjukkan bahwa perlakuan uji memberikan pengaruh yang tidak berbeda nyata $(\mathrm{P}>0,05)$ terhadap pertumbuhan keong bakau.

\section{Laju Pertumbuhan Spesifik}

Hasil perhitungan laju pertumbuhan spesifik keong bakau selama penelitian disajikan pada Gambar 2. Hasil analisis ragam menunjukkan bahwa perlakuan uji memberikan pengaruh yang tidak berbeda nyata pada hari ke-14, ke-28, ke-42 dan ke-56 (P>0,05) terhadap laju pertumbuhan spesifik.

\section{Pertumbuhan Panjang Cangkang}

Hasil perhitungan pertumbuhan panjang cangkang keong bakau selama penelitian disajikan pada Gambar 3. Hasil analisis ragam menunjukkan bahwa perlakuan uji tidak memberikan pengaruh yang berbeda nyata $(\mathrm{P}>0,05)$ terhadap pertumbuhan panjang cangkang.

\section{Tingkat Kelangsungan Hidup}

Hasil perhitungan tingkat kelangsungan hidup keong bakau selama penelitian disajikan pada Gambar 4. Hasil analisis ragam menunjukkan bahwa perlakuan uji tidak memberikan pengaruh yang berbeda nyata $(\mathrm{P}>0,05)$ terhadap tingkat kelangsungan hidup. 


\section{Kualitas Air}

Kualitas air meruperlakuan salah satu faktor yang sangat penting dalam menunjang keberhasilan suatu usaha budidaya. Selama penelitian berlangsung dilakukan pengukuran kualitas air yang terdiri dari suhu, salinitas dan $\mathrm{pH}$.

\section{Bahan Organik Pupuk Kotoran Sapi}

Hasil pengukuran kadar bahan organic media budidaya keong bakau disajikan pada tabel 2 .

\section{Hasil Uji Proksimat Daging Keong Bakau}

Hasil uji proksimat daging keong bakau disajikan pada Tabel 3.

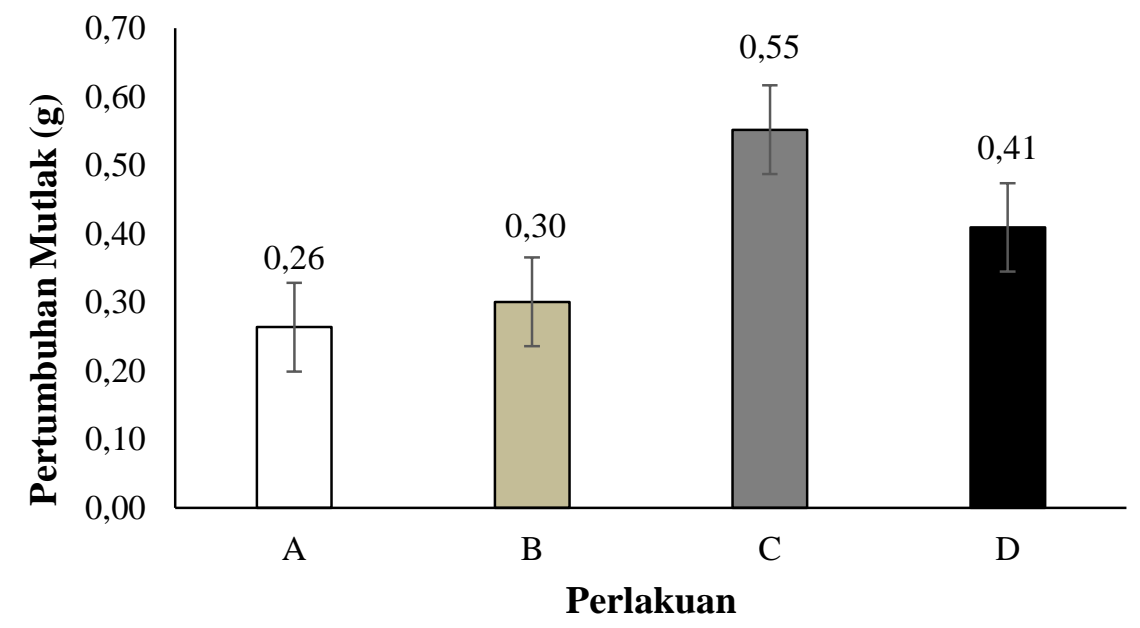

Gambar 1. Pertumbuhan Mutlak Rata-rata Keong Bakau, Perlakuan A (tanpa pemberian pupuk), Perlakuan B $\left(500 \mathrm{~g} / \mathrm{m}^{2}\right)$, Perlakuan C $\left(1000 \mathrm{~g} / \mathrm{m}^{2}\right)$ dan Perlakuan D $\left(1500 \mathrm{~g} / \mathrm{m}^{2}\right)$.

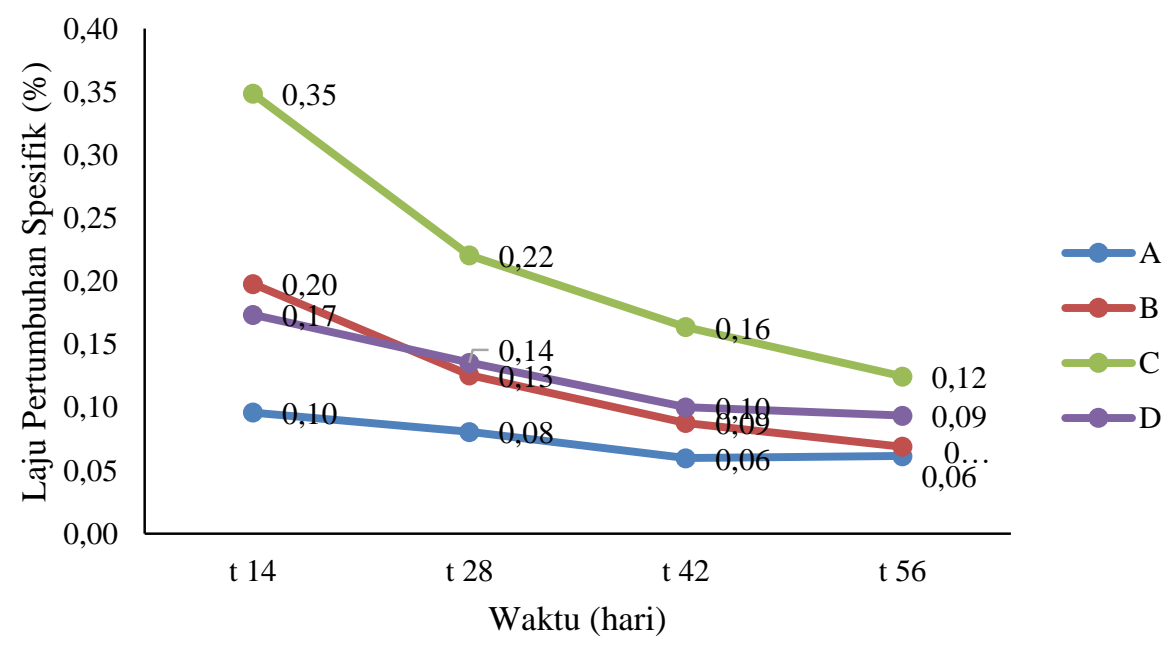

Gambar 2. Laju Pertumbuhan Spesifik Keong bakau, Perlakuan A (tanpa pemberian pupuk), Perlakuan B $\left(500 \mathrm{~g} / \mathrm{m}^{2}\right)$, Perlakuan C $\left(1000 \mathrm{~g} / \mathrm{m}^{2}\right)$ dan Perlakuan D $\left(1500 \mathrm{~g} / \mathrm{m}^{2}\right)$. 


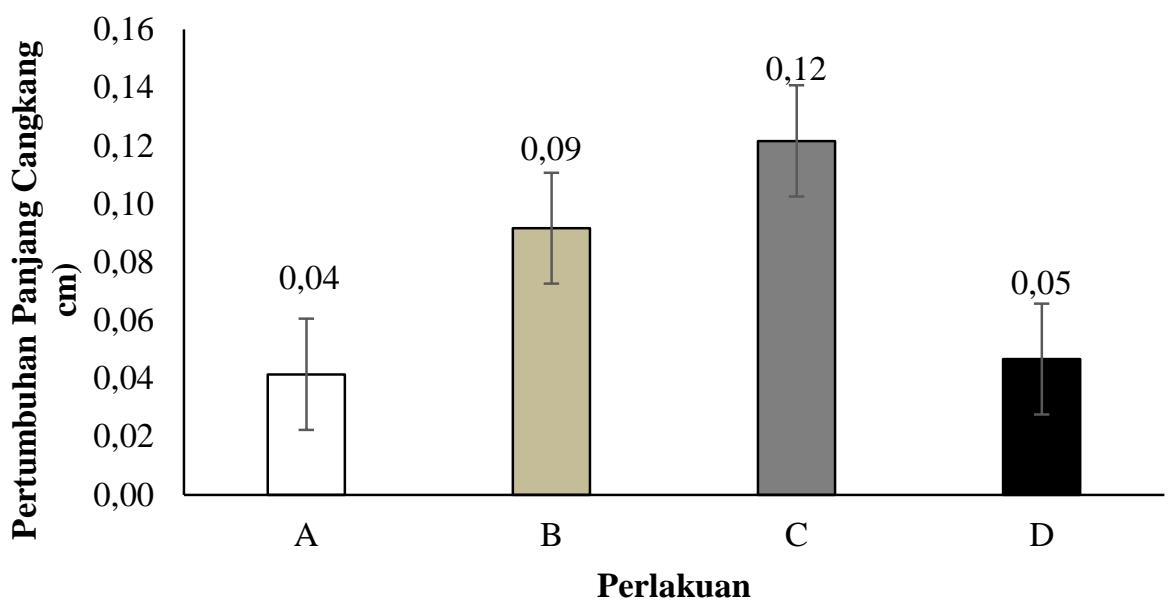

Gambar 3. Pertumbuhan Panja ng Karapaks Keong bakau, Perlakuan A (tanpa pemberian pupuk), Perlakuan B $\left(500 \mathrm{~g} / \mathrm{m}^{2}\right)$, Perlakuan C $\left(1000 \mathrm{~g} / \mathrm{m}^{2}\right)$ dan Perlakuan D $\left(1500 \mathrm{~g} / \mathrm{m}^{2}\right)$.

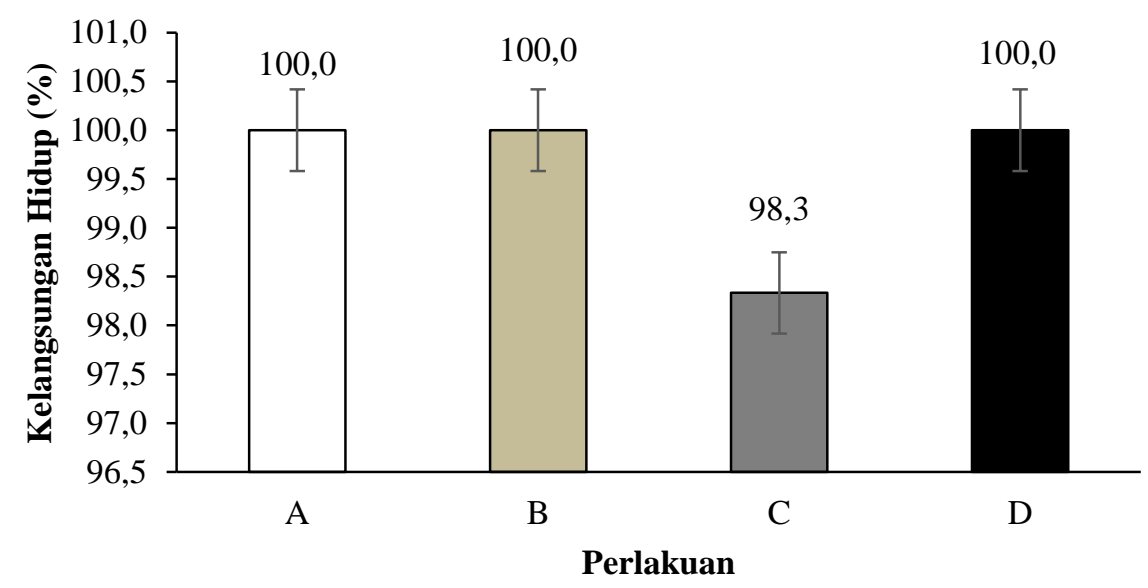

Gambar 4. Tingkat Kelangsungan Hidup Keong bakau, Perlakuan A (tanpa pemberian pupuk), Perlakuan B $\left(500 \mathrm{~g} / \mathrm{m}^{2}\right)$, Perlakuan C $\left(1000 \mathrm{~g} / \mathrm{m}^{2}\right)$ dan Perlakuan D $\left(1500 \mathrm{~g} / \mathrm{m}^{2}\right)$.

Tabel 1. Hasil pengukuran kualitas air pada media pemeliharaan selama 56 hari penelitian

\begin{tabular}{lcl}
\hline \multicolumn{1}{c}{ Parameter } & $\begin{array}{c}\text { Hasil } \\
\text { Pengukuran }\end{array}$ & \multicolumn{1}{c}{ Nilai Optimal } \\
\hline Suhu $\left({ }^{\circ} \mathrm{C}\right)$ & $26-29$ & $27-32^{\circ} \mathrm{C}$ (Keputusan Menteri Negara Lingkungan Hidup \\
\multirow{2}{*}{ Salinitas (ppt) } & $15-26$ & $\begin{array}{l}2004) \\
15-34\end{array}$ ppt (Keputusan Menteri Negara Lingkungan Hidup \\
pH & 7 & $2004)$ \\
& & $7-8,5$ (Keputusan Menteri Negara Lingkungan Hidup \\
& & $2004)$
\end{tabular}

Tabel 2. Hasil analisa kadar bahan organik media budidaya selama pemeliharaan

\begin{tabular}{ccc}
\hline \multirow{2}{*}{ Perlakuan } & \multicolumn{2}{c}{ bahan organik (\%) } \\
\cline { 2 - 3 } & Awal & Akhir \\
\hline A & 7,9 & 3,46 \\
B & 7,42 & 3,32 \\
C & 7,45 & 3,56 \\
D & 6,94 & 3,42 \\
\hline
\end{tabular}


Tabel 3. Hasil uji proksimat daging keong bakau

\begin{tabular}{ccc}
\hline Perlakuan & Kandungan Protein $(\boldsymbol{\%})$ & Kadar Air (\%) \\
\hline B & 16,46 & 79,59 \\
C & 17,26 & 82,53 \\
D & 11,29 & 78,74 \\
\hline
\end{tabular}

\section{PEMBAHASAN}

Pertumbuhan akan terjadi apabila makanan yang dibutuhkan keong bakau dapat terpenuhi untuk menunjang pembelanjaan energi dan perawatan tubuh, jika pembelanjaan energi telah terpenuhi maka makanan yang dimakan dan dicerna digunakan untuk pertumbuhan. Hasil penelitian menunjukkan pemberian pupuk kotoran sapi dengan dosis yang berbeda memberikan pengaruh yang tidak berbeda nyata terhadap pertumbuhan mutlak keong bakau selama pemeliharaan. Hal ini diduga pupuk kotoran sapi dapat mengandung bahan organik dan kandungan protein yang dibutuhkan keong bakau sehingga dapat menunjang terjadinya pertumbuhan). Kandungan bahan organik awal pada media/substrat pemeliharaan keong bakau yang diberi pupuk kotoran sapi berkisar antara 6,94\%-7,90\% sehingga dapat dimanfaatkan oleh keong bakau sebagai makanan untuk menunjang pertumbuhan. Hasil analisa proksimat daging keong bakau menunjukan bahwa kandungan protein keong bakau pada perlakuan C lebih bagus yakni sebesar $17,26 \%$ dibandingkan dengan protein keong bakau pada perlakuan B $16,46 \%$ dan perlakuan D 11,29\%. Hal ini diduga karena kandungan bahan organik Akhir pada media/substrat pemeliharaan keong bakau yang diberi pupuk kotoran sapi 1000 $\mathrm{g} / \mathrm{m}^{2}$ lebih baik 3,56\% dibandingkan kandungan bahan organik yang ada pada media substrat pemeliharaan keong bakau yang diberi pupuk kotoran sapi 500 dan $1500 \mathrm{~g} / \mathrm{m}^{2}$ dengan kandungan nilai bahan organik masing-masing sebesar 3,32\% dan 3,42\%. Hal ini sebanding dengan pernyataan Sari $d k k$. (2016), umumnya gastropoda filter feeder yang memanfaatkan bahan organik yang mengendap di substrat dasar perairan sebagai makanannya.. Hamsiah dkk. (2002), kandungan bahan organik merupakan makanan utama keong bakau. Substrat lumpur dengan nilai kandungan sedimen organik yang dapat mendukung kehidupan dari keong tersebut yang secara langsung maupun tidak langsung akan mempengaruhi pertumbuhan dari organisme ini. Pursetyo et al. (2011) pemberian pupuk yang berbeda waktunya maupun dosis pupuk yang diberikan secara langsung akan mempengaruhi bahan organik yang ada didalam media, oleh sebab itu tingginya bahan organik dalam media pemeliharaan cacing sutera akan meningkatkan jumlah partikel organik dan bakteri sehingga dapat meningkatkan jumlah bahan makanan pada media yang dapat mempengaruhi populasi cacing sutera. Amin dan Hendrajat (2012), pemberian pupuk kotoran sapi dengan dosis yang berbeda pada media pemeliharaan udang windu menunjukan pengaruh yang sama pertumbuhan mutlak

Hasil penelitian laju pertumbuhan spesifik keong bakau yang diberi pupuk kotoran sapi dengan dosis berbeda memberikan pengaruh yang tidak berbeda nyata terhadap laju pertumbuhan spesifik keong bakau. Hal ini diduga pupuk yang diberikan dapat dimanfaatkan untuk pertumbuhan. Namun secara deskriptif, laju pertumbuhan spesifik tertinggi ditunjukan pada perlakuan C. hal ini diduga karena kandungan bahan organik dan protein yang tinggi yang dapat menunjang pertumbuhan. Berdasarkan Gambar 4 menunjukan laju pertumbuhan spesifik mengalami penurunan dari hari ke-28, ke-42 dan ke-56. Hal ini diduga kandungan nutrisi pada media pemeliharaan menurun sehingga mempengaruhi pertumbuhan yang diperoleh. Hal ini sebanding dengan pernyataan Shafruddin $d k k$. (2006), pertumbuhan organisme perairan sangat dipengaruhi oleh faktor makanan dan kondisi lingkungan baik secara biologis, kimia maupun fisika yang saling berinteraksi. Proses dekomposisi memberikan manfaat yang besar dalam penyediaan makanan, ketersediaan makanan hasil dekomposisi dalam jumlah yang cukup sangat mendukung pertumbuhan. Sebaiknya pupuk diberikan setiap seminggu untuk mencegah kurangnya nutrient yang dibutuhkan untuk makan dan bertumbuh. Hamsiah $d k k$. (2002), pertumbuhan dan kelangsungan hidup 
keong bakau dipengaruhi oleh ketersediaan bahan organik pada media budidaya, apabila bahan organik pada media pemeliharaan sedikit atau kurang dapat menyebabkan terhambatnya pertumbuhan serta dapat menyebabkan kematian.

Hasil penelitian panjang total keong bakau yang diberi pupuk kotoran sapi dengan dosis yang berbeda memberikan pengaruh yang tidak berbeda nyata. Hal ini menunjukan pupuk yang diberikan mengandung bahan organik dan protein yang dibutuhkan keong bakau untuk bertumbuh. Pertumbuhan bakau dapat dilihat dari pertumbuhan bobot maupun pertumbuhan panjang cangkang. Namun secara deskriptif, pertumbuhan panjang cangkang tertinggi diperoleh pada keong bakau yang diberi perlakuan C. Hal ini sebanding dengan pernyataan Shafruddin $d k k$. (2006), ketersediaan nutrisi dalam jumlah mencukupi dan kondisi lingkungan yang seimbang mendorong pertumbuhan yang cepat. Penelitian mengenai pertumbuhan gastropoda berdasarkan panjang atau lebar me,buhtukan waktu yang cukup lama karena pertambahan panjang atau lebar cangkang sangat kecil. Menurut Dharma (1998),pertumbuhan keong bakau dan kerang jauh lebih cepat pada saat umurnya masih muda dibandingkan pada saat dewasa, misalnya kecepatan tumnuh keong cypraea spadicea yaitu : keong muda yang berukuran $30 \mathrm{~mm}$ menjadi $40 \mathrm{~mm}$, kecepatan tubuhnya $2 \mathrm{~mm} /$ minggu (dibutuhkan waktu 5 minggu),keong yang berukuran $40 \mathrm{~mm}$ menjadi $43 \mathrm{~mm}$ kecepatan tubuhnya $0,5 \mathrm{~mm} /$ minggu (dibutuhkan waktu 6 minggu), keong yang berukuran $43 \mathrm{~mm}$ menjadi $45 \mathrm{~mm}$, kecepatan tumbuhnya $0,25 \mathrm{~mm} /$ minggu (dibutuhkan waktu 8 minngu).

Hasil penelitian kelangsungan hidup keong bakau yang diberi pupuk kotoran sapi dengan dosis berbeda memberikan pengaruh yang sama terhadap kelangsungan hidup keong bakau selama pemeliharaan. Kelangsungan hidup selain dipengaruhi oleh ketersediaan pakan juga dipengaruhi oleh kualitas media pemeliharaan hal ini didukung oleh Gambar 4, dimana semakin lama masa pemeliharaan maka semakin rendah pertumbuhan yang dihasilkan. Hal ini diduga kandungan nutrisi media pemeliharaan sedikit atau berkurang, sehingga terjadi persaingan makanan dan keong bakau yang tidak memperoleh makanan akan mati.
Hamsiah dkk. (2002), kelangsungan hidup keong bakau dipengaruhi oleh ketersediaan bahan organik pada media pemeliharaan. Keong yang tidak mendapatkan makanan akan mengalami kematian. Selanjutnya, Rahmawati (2013), suhu ekstrim dapat mengakibatkan kematian yang tinggi.

Kualitas air sangat berperan penting dalam menunjang pertumbuhan dan kelangsungan hidup keong bakau. semakin baik baku mutu air yang digunakan dan menyerupai habitat aslinya selama pemeliharaan, maka semakin baik pula pertumbuhan dan kelangsungan hidup yang dihasilkan. Berdasarkan hasil pengukuran kualitas air selama penelitian menujukan media pemeliharaan masih dalam kisaran baku mutu (kisaran optimum) dan layak untuk pertumbuhan dan kelangsungan hidup keong bakau. Kualitas air yang diamati selama pemeliharaan adalah suhu, $\mathrm{pH}$, dan salinitas. Hasil pengukuran suhu selama penelitian diperoleh kisaran suhu $26^{\circ} \mathrm{C}-29^{\circ} \mathrm{C}$, salinitas berkisar 15-26 ppt dan $\mathrm{pH}$ berkisar 7. Hal ini sebanding dengan pernyataan Keputusan Menteri Negara Lingkungan Hidup (2004), suhu normal untuk wilayah mangrove yaitu 27$32^{\circ} \mathrm{C}$. nilai $\mathrm{pH}$ normal berkisar 7-8,5 dan salinitas berkisar $15-34$ ppt. Kualitas air yang optimum dapat menunjang pertumbuhan dan kelangsungan hidup keong bakau.

\section{KESIMPULAN}

Adapun kesimpulan yang dapat ditarik dari penelitian ini yaitu pemberian pupuk kotoran sapi dengan dosis yang berbeda memberikan pengaruh yang tidak berbeda nyata terhadap pertumbuhan mutlak, pertumbuhan Panjang cangkan, laju pertumbuhan spesifik hari ke-14, ke-28, ke-42 dan ke 56 dan kelangsungan hidup keong bakau. Penelitian ini menyimpulkan bahwa pemberian pupuk kotoran sapi dapat meningkatkan pertumbuhan keong bakau.

\section{REFERENSI}

Amin, M dan Hendrajat, E.H. 2012. Penggunaan Pupuk Organik Kotoran Sapi pada Budidaya Udang Windu, Penaeus monodon dengan Dosis Pupuk Berbeda. Seminar Nasional Tahunan IX Penelitian Perikanan dan Kelautan. 
Berova, M., Karanatsidis, G., Sapundzhieva, K., and Nikolova, V. 2010. Effect of Organic Fertilization on Growth and Yield of Pepper Plants (Capsicum annum L.). Journal Folia Horticulturae, 22(1):37. https://doi.org/10.2478/fhort-20130143

Dharma, B. 1988.siput dan kerang kerangan Indonesia. Sarana Graha, Jakarta.

Effendi, M.I. 1997. Biologi Perikanan. Yayasan Pustaka Utama.

Effendi, H. 2003. Telaah Kualitas Air. Bagi Pengelolaan Sumber Daya dan Lingkungan Perairan. Kanisius. Yogyakarta.

Hamsiah, Djokosetiyanto, D., Adiwilaga E. M., dan Nirmala, K. 2002. Peranan keong bakau (Telescopium telescopium) Sebagai Biofilter Dalam Pengelolaan Limbah Budidaya Tambak Udang Intensif. Tesis. Program Pasca Sarjana Institut Pertanian Bogor.

Keputusan Menteri Lingkungan Hidup No. 51. 2004. Baku Mutu Air Laut Untuk Biota Laut. Jakarta.

Kurnia, A., Muskita, W. H., Astuti, O dan Hakim, A. 2016. Utilization of Telecopium Mussel Meal as an Alternatife Protein Source in the Diet of Black Tiger Shrimp, Penaeus monodoni. Jurnal Internasional Journal of science and Research (IJSR). 5(1): 1-6.

Kusriani, K., Widjanarko, P., \& Rohmawati, N. (2012). Uji pengaruh sublethal pestisida diazinon 60 EC terhadap rasio konversi pakan (FCR) dan pertumbuhan ikan Mas (Cyprinus carpio L.). Jurnal Penelitian Perikanan, 1(1): 36-42.

Masithah, E.D., Ningrum, N.A., dan Sigit, S. 2011. Pengaruh Pemberian Bakteri Bacillus pumilus pada Kotoran sapi Sebagai Pupuk Terhadap Jumlah Kandungan Klorofil Dunaliella salina. Jurnal Ilmiah Perikanan dan Kelautan, 3(1): 53-59.

Pursetyo, K. T., Satyantini, W. H., \& Mubarak, A. S. (2011). Pengaruh Pemupukan Ulang Kotoran Ayam Kering Terhadap Populasi Cacing Tubifex tubifex. Jurnal Ilmiah Perikanan dan Kelautan, 3(2): 177-182.

Rahmawati, G. 2013. Ekologi Keong Bakau (Telescopium telescopium, Linnaeus,
1758) pada Ekosistem Mangrove Pantai Mayangan, Jawa Barat. Skripsi. Fakultas Perikanan dan Ilmu Kelautan. Institut Pertanian Bogor. Bogor.

Sari, W.P., Bahtiar dan Emiyanti. 2016. Studi Preferensi Habitat Siput Tutut (Bellamya javanica) di Desa Amonggedo Kabupaten Konawe. Jurnal Manajemen Sumber Daya Perairan, 1(2): 213-224.

Shafruddin, D., Parlinggoman, B.R. dan Sumantadinata. 2006. Pertumbuhan dan Produksi Larva Cacing Darah Chironomus sp. pada Media yang Dipupuk Kotoran Ayam Dosis 1,0-2,5 Gram/Liter. Jurnal akuakultur Indonesia, 5(1): 97-102

Zahidah, W. Gunawan dan U. Subhan. 2012. Pertumbuhan Populasi Daphnia sp. yang Diberi Pupuk Limbah Budidaya Karamba Jaring Apung (KJA) di Waduk Cirata yang Telah Difermentasi EM4. Jurnal Akuatik., 3(1):84-94. 